\title{
XXIV. On a planetary analogy; or a law of motion pervading and connecting all the planetary orbits
}

\author{
Mr.J. Utting
}

To cite this article: Mr. J. Utting (1823) XXIV. On a planetary analogy; or a law of motion pervading and connecting all the planetary orbits , Philosophical Magazine Series 1, 62:304, 119-121, DOI: $10.1080 / 14786442308644391$

To link to this article: http://dx.doi.org/10.1080/14786442308644391

里 Published online: 23 Jul 2009.

Submit your article to this journal $[\pi$

Џ Article views: 2

Q View related articles $\square$ 
it might be found in many other places; certainly it must have been formed in the old Franklin furnace, in Sussex county New-Jersey, where so many fruitless attempts were made to work the Franklinite.

Before I conclude these remarks, I must observe, that it does not appear that the presence of zinc affects the properties of iron. In Belgium the iron is of good quality; and it is an interesting fact, that the bar-iron of Ancram is in great demand at 8120 per ton, a higher price than is at present paid for any imported iron. The castings from the Ancram furnace are in such a repute, that no other pigs are used at the West Point Foundry for the heavy guns (32 and 42 pounders) now casting for the United States' navy.

The Ancram furnace equals, in beauty of workmanship, and economy of means, any that we have seen; and we entertain no doubt, that all works carried on with such admirable perfection, must and will always prove equally honourable and profitable to their owners and directors.

XXIV. On a Planetary Analogy; or a Law of Motion pervading and connecting all the Planetary Orbits. By $M r$. J. UtTing.

To the Edilors of the Plilosophical Magazine and Journal.

Lynn Regis, June 21, 189:?.

THE following beautiful analogy which olvtains in the mo1 tions of the planetary orbs has, I belicre, never been described by any astronomical writer, or is not generally knowin, viz. If the mean orbicular motion of each planet in its orbit, be multiplied by the square root of its mean distance from the sun, a product will be obtained common to all the plancts: for instance, if the orbicular motion in miles of each planet in one sidereal day, be multiplied by the square root of its mean distance from the sun, the product will be 15.634.588.176 miles, a constant quantity for all the planets, as the mean velocity of the planets, multiplied by the square root of their respective mean distance, is always a constant quantity.

The same analogy obtains in each respective system of satellites; for, if the velocity of a satellite be multiplied by the square root of its mean distance from its primary, a conslant product will also be produced in each respective system of satellites; and if this constant product be multiplied by the square root of the reciprocal of the sun's attractive power, and that of their respective primaries, the same result will be produced as that which obtains in the planetary motions, as above. Thus a constant product, or quantity, obtains in the motions 
of the planets, and their respective systems of satellites, extending to the whole planetary system, resulting from the periodic times and mean distances of the planets, with the periodic times and mean distances of their satellites, compounded with the attractive power of the sun, as compared with that of the primary planets, around which each respective system of satellites circulates; viz.

Let $\mathrm{V}, \mathrm{V}^{\prime}, \mathrm{V}^{\prime \prime}$, \&c. represent the velocities of the planets in their orbits; and $\sqrt{ } \mathrm{D}, \mathfrak{}^{\prime} \mathrm{D}^{\prime}, \sqrt{ } \mathrm{D}^{\prime \prime}$, \&c. the square roots of their mean distances from the sun. Let also $v, v^{\prime}, v^{\prime \prime}$, \&c. represent the velocities of their respective satellites; and the $\sqrt{ } d, \sqrt{ } d^{\prime}, \sqrt{ } d^{\prime \prime}, 8 \mathrm{c}$. the square roots of their mean distances from their primaries. Let the square root of the sun's attractive power, that of each planet being unity, be denoted by $v^{\prime} m, \sqrt{ } m^{\prime}, \sqrt{ } m^{\prime \prime}, \&$ c. respectively.

Whence we have $V \times \sqrt{ } D=V^{\prime} \times \sqrt{ } D^{\prime}=V^{\prime \prime} \times \sqrt{ } D^{\prime \prime} \& c$. a constant quantity for the primary planets. And $v \times \sqrt{ } d=$ $v^{\prime} \times \sqrt{ } d^{\prime}=v^{\prime \prime} \times \sqrt{ } d^{\prime \prime}$, \&c. a constant quantity for each respective system of satellites. Also, $v \times \sqrt{ } d \times \sqrt{ } m_{0}=v^{\prime} \times \sqrt{ } d^{\prime} \times \sqrt{ } m^{\prime} .=$ $v^{\prime \prime} \times \sqrt{ } d^{\prime \prime} \times \sqrt{ } m^{\prime \prime}$, \&c. a constant quantity equal to that in the first analogy. Whence $\frac{V \times}{v \times \sqrt{ } d \times} \frac{\mathrm{D}}{\sqrt{ } m}=0 .=\frac{\mathrm{V}^{\prime} \times \sqrt{ } \mathrm{D}^{\prime}}{v^{\prime} \times \sqrt{ }^{d^{\prime}} \times \sqrt{ }^{\prime \prime}}=$ $0 .=\frac{\mathrm{V}^{\prime \prime} \times \sqrt{ } \mathrm{D}^{\prime \prime}}{v^{\prime \prime} \times \sqrt{d^{\prime \prime}} \times \sqrt{ }^{\prime \prime} m^{\prime \prime}}=0.8 \mathrm{c}$.

The following general analogy also obtains, viz. As $\mathrm{V}: \mathrm{V}^{\prime}:: \sqrt{ } \mathrm{D}^{\prime}: \sqrt{ } \mathrm{D}$; also as $v: v^{\prime}:: \sqrt{ } d^{\prime}: \sqrt{ } d$ \&c. where the product of the two extreme terms will always be equal to the product of the two mean ones, whatever may be the planets or satellites fixed on.

The following table exhibits the result of my calculations in elucidation of this analogy.

Tabular View of the Analogy which oblains in the Planetary System.

\begin{tabular}{|c|c|c|c|c|c|c|c|}
\hline 密 & $\begin{array}{l}\text { Sidereal periods } \\
\text { in sid. days. }\end{array}$ & $\begin{array}{l}\text { Mean dist. } \\
\text { in niles. }\end{array}$ & $\begin{array}{c}\text { Nass of } \\
\text { the } \odot \\
\text { each } \\
\text { planet } \\
=1 .\end{array}$ & $\begin{array}{c}\text { Square } \\
\text { root of } \\
\text { the } \odot^{\prime} \text { 's } \\
\text { mass. }\end{array}$ & $\begin{array}{l}\text { Square } \\
\text { root of } \\
\text { mean } \\
\text { dist. in } \\
\text { miles. }\end{array}$ & $\begin{array}{l}\text { Velocity } \\
\text { in one } \\
\text { sidereal } \\
\text { day in } \\
\text { miles. }\end{array}$ & $\begin{array}{c}\text { Constant } \\
\text { product in } \\
\text { miles. }\end{array}$ \\
\hline$\phi$ & $88 \cdot 2101005$ & $36 \cdot 387308$ & ...... & & \multicolumn{3}{|c|}{$6032 \cdot 19 \times 2591860=15634588170$} \\
\hline$\stackrel{+}{9}$ & $225 \cdot 3159734$ & $67 \cdot 993235$ & & & \multicolumn{3}{|c|}{$824580 \times 1896067=15634588170$} \\
\hline$\stackrel{+}{\oplus}$ & $366 \cdot 2563835$ & $94 \cdot 000000$ & $337102^{\circ}$ & $580 \cdot 605$ & \multicolumn{3}{|c|}{$9695.36 \times 1612585=15634588170$} \\
\hline$\delta$ & $688 \cdot 8604607$ & 143.227108 & & & \multicolumn{3}{|c|}{$11967.75 \times 1306393=15634588170$} \\
\hline 4 & $4344 \cdot 4468810$ & $488 \cdot 908265$ & $1066 \cdot 09$ & $32 \cdot 6510$ & $22111 \cdot 27$ & \\
\hline$\widehat{h}$ & $10787 \cdot 7763273$ & 896.517987 & 351208 & $59 \cdot 2628$ & $29941 \cdot 91$ & \multicolumn{2}{|c|}{$522164=15634588170$} \\
\hline $\mathrm{H}$ & $30772 \cdot 7323350$ & 1803218792 & 19504 & $139 \cdot 6567$ & $42464 \cdot 32$ & \multicolumn{2}{|c|}{$368182=15634588170$} \\
\hline
\end{tabular}


Sattellite of the Earth.

\begin{tabular}{|c|c|c|c|c|c|c|c|}
\hline 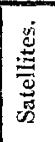 & $\begin{array}{l}\text { Sid. period } \\
\text { in sid. days. }\end{array}$ & $\begin{array}{c}\text { Mean } \\
\text { dist. in } \\
\text { miles. }\end{array}$ & $\begin{array}{l}\text { Square } \\
\text { root of } \\
\text { mean dist. } \\
\text { in miles. }\end{array}$ & $\begin{array}{l}\text { Velo- } \\
\text { city in } \\
\text { one sin. } \\
\text { day in } \\
\text { miles. }\end{array}$ & $\begin{array}{c}\text { Constant } \\
\text { poduct for } \\
\text { cach system } \\
\text { of saiellites } \\
\text { in miles. }\end{array}$ & $\begin{array}{l}\text { Square } \\
\text { not of } \\
\text { the } Q \text { 's } \\
\text { mass. }\end{array}$ & $\begin{array}{l}\text { Constant } \\
\text { product in } \\
\text { miles. }\end{array}$ \\
\hline$D$ & $27 \cdot 3964621$ & 239780 & \multicolumn{5}{|c|}{$489674 \times 51992=26928100 \times 580.605=15634588170$} \\
\hline $\begin{array}{l}1 \\
2 \\
3 \\
4\end{array}$ & $\begin{array}{r}1 \cdot 77.39813 \\
3 \cdot 5609034 \\
7 \cdot 1711105 \\
16 \cdot 7344602\end{array}$ & $\left|\begin{array}{r}263110 \\
419160 \\
668630 \\
1176020\end{array}\right|$ & \multicolumn{5}{|c|}{$\begin{array}{l}\text { Satellites of Jupiter. } \\
513 * 239 \times 932975=478859200 \times 32 \cdot 6510=15634588170 \\
647 \cdot 426 \times 739605=478839200 \times 32 \cdot 6510=15634588170 \\
817 \cdot 699 \times 585594=478839200 \times 32 \cdot 6510=15634588170 \\
1084 \cdot 444 \times 441553=473839200 \times 32 \cdot 6510=15634588170\end{array}$} \\
\hline $\begin{array}{l}1 \\
2 \\
3 \\
4 \\
5 \\
6 \\
7\end{array}$ & $\begin{array}{r}0.9452910 \\
1.3730915 \\
1.8929684 \\
2.7469802 \\
4.5298580 \\
15.9889550 \\
79.5467885\end{array}$ & $\begin{array}{r}\text { Sate } \\
116360 \\
149300 \\
184860 \\
236950 \\
330730 \\
766710 \\
2234420\end{array}$ & \multicolumn{5}{|c|}{$\begin{array}{l}\text { llites, and Ring of Saturn. } \\
341 \cdot 112 \times 773400=263818000 \times 59 \cdot 2628=15634588170 \\
356 \cdot 400 \times 682760=263818000 \times 59 \cdot 2628=15634588170 \\
429 \cdot 965 \times 613595=263818000 \times 59 \cdot 2628=15634588170 \\
486 \cdot 775 \times 541973=263818000 \times 59 \cdot 2628=15634588170 \\
575 \cdot 091 \times 458741=263818000 \times 592628=15634588170 \\
875 \cdot 618 \times 301293=263818000 \times 59 \cdot 2628=15634588170 \\
1494 \cdot 798 \times 176491=263818000 \times 59 \cdot 2628=15634588170\end{array}$} \\
\hline & 0.4402692 & 69914 & \multicolumn{5}{|c|}{ 1. $264.412 \times 997754=263818000 \times$} \\
\hline $\begin{array}{l}1 \\
2 \\
3 \\
4 \\
5 \\
6\end{array}$ & $\begin{array}{r}5 \cdot 9087398 \\
8 \cdot 7306375 \\
10 \cdot 9911093 \\
13.4927396 \\
38 \cdot 1792417 \\
107 \cdot 9892458\end{array}$ & $\begin{array}{l}222960 \\
289210 \\
337230 \\
386630 \\
773480 \\
1546980\end{array}$ & \multicolumn{5}{|c|}{$\begin{array}{l}\text { Satellites of Uranus. } \\
472 \cdot 186 \times 237089=111950150 \times 139 \cdot 6567=15634588170 \\
537 \cdot 812 \times 208159=111950150 \times 139 \cdot 6567=15634588170 \\
580 \cdot 714 \times 192730=111950150 \times 139 \cdot 6567=15634588170 \\
621 \cdot 797 \times 180043=111950150 \times 139 \cdot 6567=15634588170 \\
879 \cdot 476 \times 127292=111950150 \times 139 \cdot 6567=15634588170 \\
1243.775 \times 90008=111950150 \times 139 \cdot 6567=15634588170\end{array}$} \\
\hline
\end{tabular}

Noтr.-The periodic times of the planets and satellites were taken from the fourth edition of Laplace's Système du Monde, the time being converted from solar to sidereal days in the proportion of 1.0027378 to $\mathrm{J}$. The mass or attractive power of the sun, and planets, was also taken from the same work, from which with the periodic time, and constant product, the distrnces of all the satellites from their primaries were computed. The distance of the ring of Satu'n, is the distance from the centre of the planet to the centre of attraction in the cylinder of the ring, or the centrc of gravity of a satellite, supposing all the particles of matter in the ring to be condensed into a globular form, and whose sidereal period is equal to that of the rotation of the ring.

XXV. State of the Thermometer at Smyrna for every Day in the Year 1820 (bcing the Year of the great Eclipse, and Leapyear,) taken in the Shade four timcs every Day; viz. 9 A.M., Noon, 6 P.M., Midnight. Communicated from Smyrna by a Correspondent to Dr. T. Forster.

Vol. 62. No. 304. Aug. 1823. 